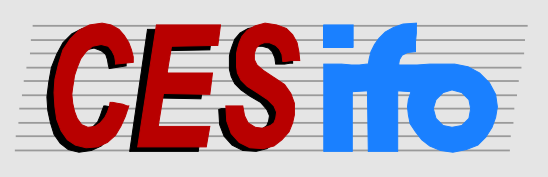

\title{
Working
}

Papers

www.cesifo.org/wp

\section{The Macroeconomic Policy Challenges of Balance Sheet Recession: \\ Lessons from Japan for the European Crisis}

\author{
Gunther Schnabl
}

\author{
CESIFO WORKING PAPER NO. 4249 \\ CATEGORY 7: MONETARY POLICY AND INTERNATIONAL FINANCE \\ MAY 2013
}

An electronic version of the paper may be downloaded

- from the SSRN website:

- from the RePEc website:

- from the CESifo website:

www.SSRN.com

www.RePEc.org

www.CESifo-group.org/wp

\section{CESifo}




\title{
The Macroeconomic Policy Challenges of Balance Sheet Recession: Lessons from Japan for the European Crisis
}

\begin{abstract}
The paper compares the boom-and-bust cycles in Japan and Europe with respect to the reasons for excessive booms, the characteristics of the crises, and the (potential) effects of the crisis therapies. As in Japan the consequence of expansionary monetary and fiscal policies is the hysteresis of the low-interest rate and high government debt environment, the erosion of the allocation and signaling function of the interest rate, the gradual quasi-nationalization of financial institutions as well as gradual real income losses, the economic policy implication for Japan and Europe is the timely exit from the current crisis therapies.
\end{abstract}

JEL-Code: E320, E420, E580.

Keywords: Japan, Europe, bubble economy, European crisis, low interest rate policy, government debt sustainability, balance sheet recession.

\author{
Gunther Schnabl \\ Leipzig University \\ Institute for Economic Policy \\ Grimmaische Str. 12 \\ Germany - 04109 Leipzig \\ schnabl@wifa.uni-leipzig.de
}

I thank Osamu Ishikawa, Raphael Fischer and Stefan Angrick for valuable support. 


\section{Introduction}

While a growing number of European countries are struggling for the consolidation of their general government deficits, the crisis seems to have become the normal course of life. Whereas up to recently deep crises were followed by buoyant recoveries, the European financial, debt and economic crisis seems to turn into a chronic disease. Reiterated rescue activities by governments, central banks and supranational institutions were able to prevent major meltdowns, but could despite buoyant German economic activity not trigger a sustained European recovery. Will the persistent instability in a rising number of European crisis countries (now including economic giants such as Italy and possibly France) lead into uncontrolled contagion and financial meltdown? Or do we stand at the beginning of a persistent lingering crisis as it is observed in Japan since more than two decades?

Japan has not only moved through a boom-and-bust cycle - the so called bubble economy almost 20 years earlier than Europe but has also made important experiences with a crisis management in form of monetary expansion, unconventional monetary policy making, fiscal expansion and recapitalization of banks. Although Japan has reached the (close to) zero interest rate environment more than a decade earlier than Europe and gross general government debt (in terms of GDP) has gone far beyond the levels, which are today prevalent in Europe, growth continues to stagger.

Previous papers have analyzed the Japanese crisis therapies and the consequences for the Japanese financial sector and growth (e.g. Mikitani and Posen 2000, Bayoumi and Collyns 2000, Sekine, Kobayashi and Saita 2003, Caballero, Hoshi und Kashyap 2008, Ueda 2012). The origins of the European crisis have been associated with the euro introduction (Berger and Nitsch 2011), diverging competitiveness (Zemanek 2010), speculation inherent to human action (De Grauwe 2011), and uncoordinated fiscal policies (Schnabl and Wollmershäuser 2011). While Ueda (2012) compares the Japanese post bubble crisis with the subprime crisis in the US, up to the present a comprehensive comparison between the boom-and-bust cycles in Japan and Europe including an analysis of the effects of Japan's crisis management have not been made.

The comparison between the boom-and-bust cycles in Japan and Europe with respect to the origins of exuberant booms, the crisis patterns, the crisis therapies, and the (possible) effects of the crisis therapies shows that despite significant differences important similarities exist. With the growing socialisation of risk Europe follows the Japanese economic policy decision- 
making pattern, with - possibly - a similar outcome for European growth and welfare perspectives. The gradual decline in real income in Japan should be incentive enough for a turnaround in economic policy making in both Europe and Japan.

\section{Monetary cum Fiscal Expansion as Origin of the Crisis}

The exuberance on the Japanese stock and real estate markets in the second half of the 1980s originated inter alia ${ }^{1}$ in a combination of expansionary monetary and fiscal policies (Schnabl and Hoffmann 2008). The starting point of the Japanese bubble economy was a political conflict about the US-Japanese trade imbalance, which had emerged after the liberalization of Japanese international capital flows during the first half of the 1980s. The United States put pressure on Japan to cure the trade imbalance by a strong revaluation of the yen against the dollar (McKinnon and Ohno 1997). With the Plaza-Agreement of September 1985 a substantial appreciation of the Japanese yen against the US dollar was announced and underpinned by a monetary tightening in Japan (Funabashi 1989). This opened the door for one-way bets on yen appreciation (McKinnon and Ohno 1997), which led to a yen appreciation far beyond the targeted range. The resulting sharp decline of Japanese exports and a high-yen induced recession triggered attempts of the Bank of Japan to soften the appreciation pressure by short-term interest rate cuts from roughly $8 \%$ in 1985 to $3.5 \%$ in 1987 (Figure 1).

The resulting easing of credit conditions not only faciliated investment in the Japanese industry to regain international competitiveness, but also contributed to an unprecedented stock market and real estate boom. As shown in Figure 2 the Nikkei 225 hiked from about 15.000 points in January 1985 to closely below 40.000 points in December 1989. Also real estate prices, in particular in the metropolitan areas, increased fast. In densely populated Japan real estate became a widely used collateral for speculative stock purchases. The boom on stock and real estate markets was further fuelled by an expansionary fiscal policy following the Louvre-Accord (February 1987): After the yen appreciation had failed to reduce the Japanese current account surplus ${ }^{2}$, Japan was urged to stimulate the domestic economy by

The literature further identifies the liberalization of capital markets and the resulting erosion of bank-based lending as an important determinant of the bubble economy. (See also footnote 3.)

2 The Japanese current account balance as the target of the yen appreciation remained more or less unchanged, because not only exports but also imports declined (McKinnon and Ohno 1997) (Figure 3). 
fiscal expansion to reduce the current account surplus via the import channel (Funabashi 1987). Monetary expansion became paired with fiscal expansion.

Figure 1: Money Market Interest Rates in Japan and Europe after Crisis Events

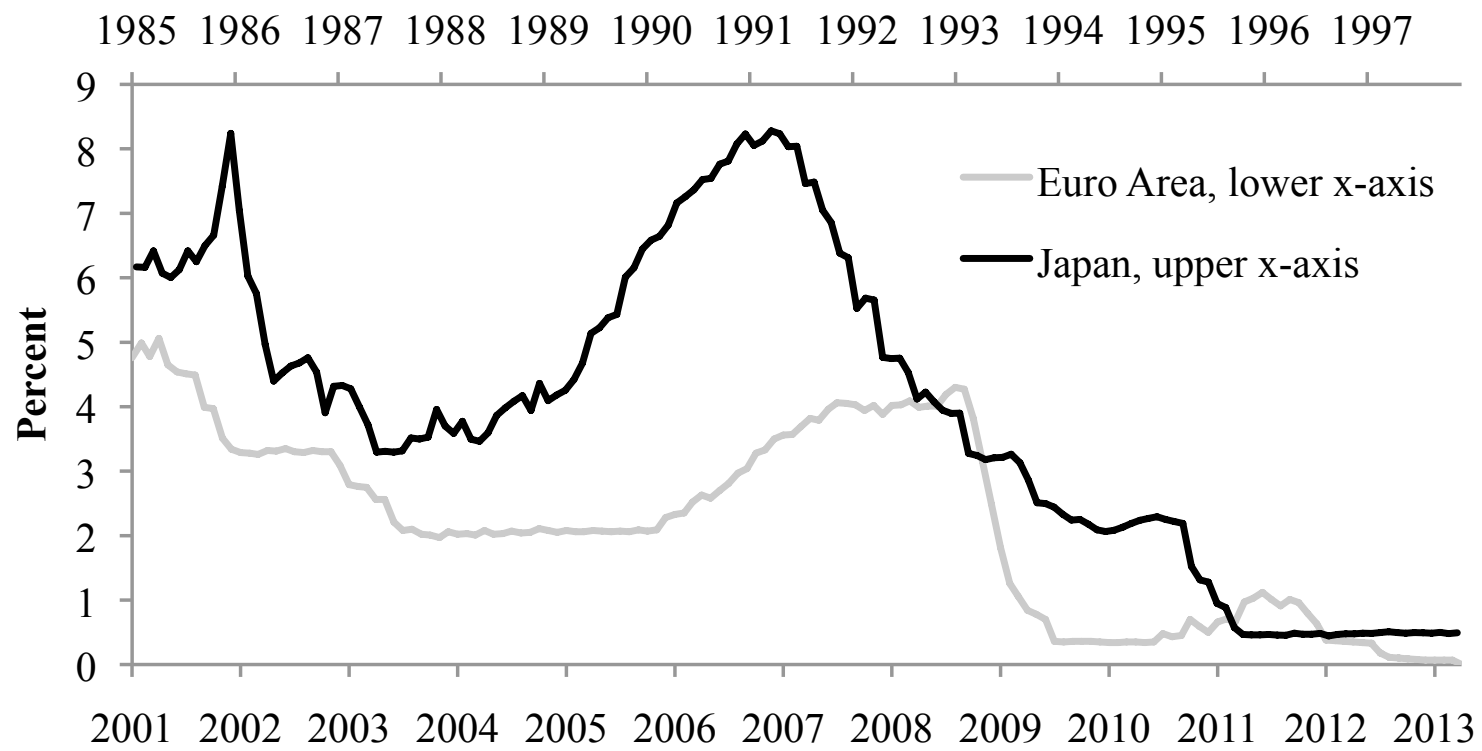

Source: IMF International Financial Statistics, via Datastream. The (exogeneous) crisis events are the yen appreciation following the Plaza Agreement in September 1985 for Japan and the sharp decline of stocks prices following the bursting of the dotcom bubble during the year 2000 for Europe.

Also in the European (Monetary) Union the origin of the excessive boom events in the later crisis countries can inter alia ${ }^{3}$ be traced in a policy-mix of expansionary fiscal and monetary policies (Schnabl und Wollmershäuser 2013). In contrast to Japan the trigger of an expansionary monetary policy by the European Cental Bank was not a trade imbalance, but financial market instability in form of a dramatic decline of stock prices after the bursting of the dotcom bubble. The intra-euro area current account positions in Europe were widely contained up to the turn of the millennium (Figure 3). Before, during and after the speculation booms in Europe the current account position of the euro area as a whole remained roughly balanced. The rising intra-European current account imbalances during the boom period can

Further possible reasons for the speculation booms and rising intra-European current account imbalances were provided in section 1. As in Japan the liberalization of financial markets is assumed to have played an important role. In this context, however, it is to be scrutizied to what extend the liberalization process of financial markets has been driven by monetary expansion, as rising money supply increases the need for investment opportunities, what xconstitutes a push factor for lobbying pressure towards financial market liberalization. 
be seen more as a symptom of rather than as the reason for the speculation booms (Schnabl and Wollmershäuser 2013).

Two years after the euro introduction, the European Central Bank sharply cut interest rates in response to the bursting dotcom bubble from about $5 \%$ in early 2001 to $2 \%$ in 2003 , i.e. to a historical low in Europe (Figure 1). Figure 1 also provides a comparison of the central bank response to the respective exogeneous shocks, i.e. the Plaza Agreement in September 1985 for Japan (and the resulting yen appreciation) (lower x-axis) as well as the bursting of the dotcom bubble during 2000 for Europe (and the resulting decline in stock prices) (upper x-axis). The interest rate cuts of the European Central Bank started from a lower level and lasted longer than the interest rate cuts of the Bank of Japan.

Figure 2: Stock Price Movements in Response to Monetary Expansion

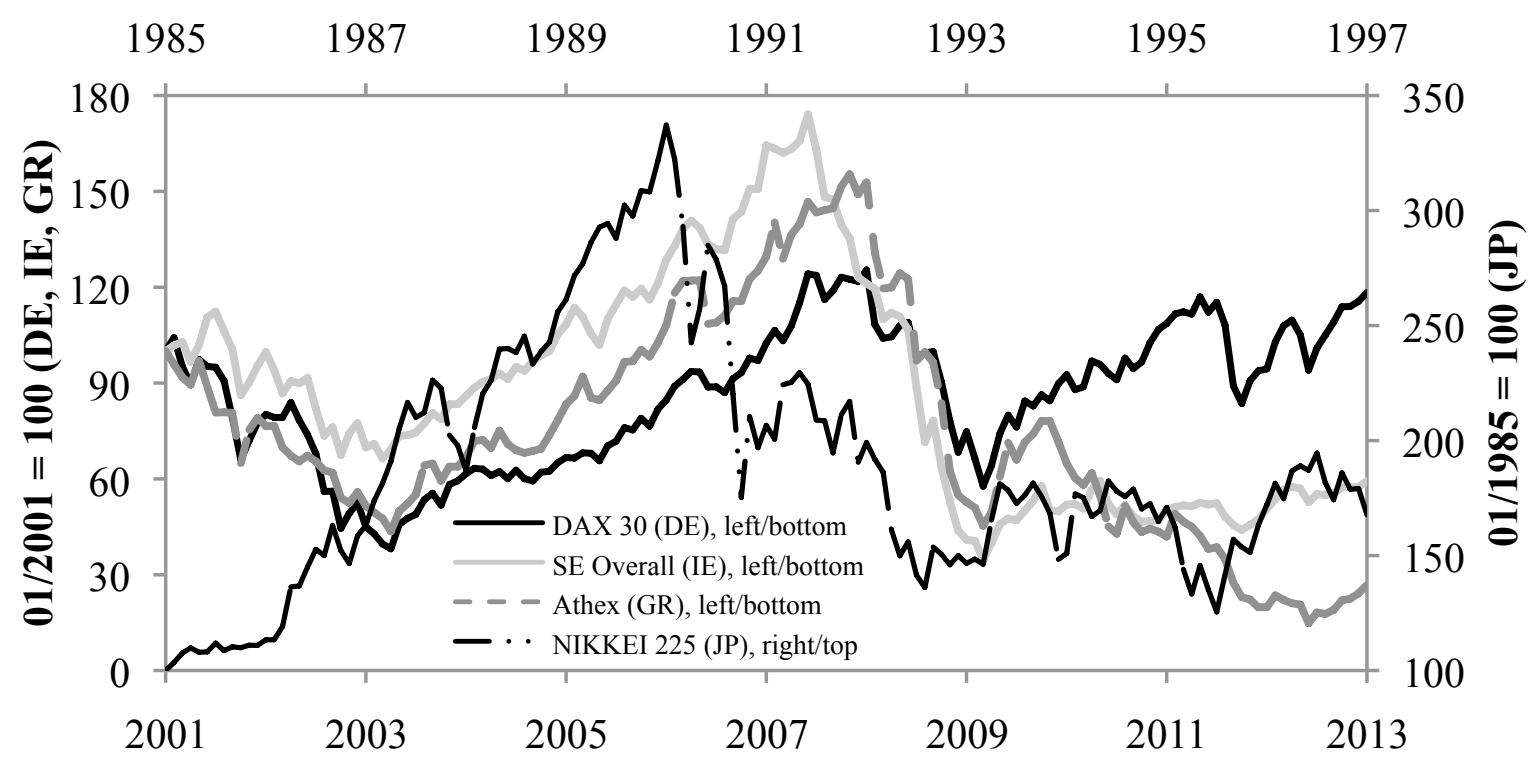

Source: National stock markets (Nikkei, Deutsche Börse, Irish Stock Exchange, Athens Stock Exchange), via Datastream.Japan onupper x-axis, Europe on lower X-axis.

The monetary expansion starting in the year 2001 was paired with asymmetric fiscal policies stances in different parts of Europe (Schnabl and Wollmershäuser 2013). In Germany - facing the long-term consequences of the German unification in form of low international competitiveness, unprecedented high unemployment and historically high government debt sustained efforts set in to consolidate government finance (Schnabl und Zemanek 2011). The public consolidation process was accompanied by a thorough restructuring process in the 
German enterprise sector, which aimed at restoring its international competitiveness, which had substantially declined during the unification boom. The policy mix of expansionary monetary, restrictive fiscal and restrictive wage policies ${ }^{4}$ favoured capital outflows to the periphery of the European Monetary Union and other member states of the European Union (Abad et al. 2013).

\section{Figure 3: Current Account Imbalances of US and Japan, and in Europe}

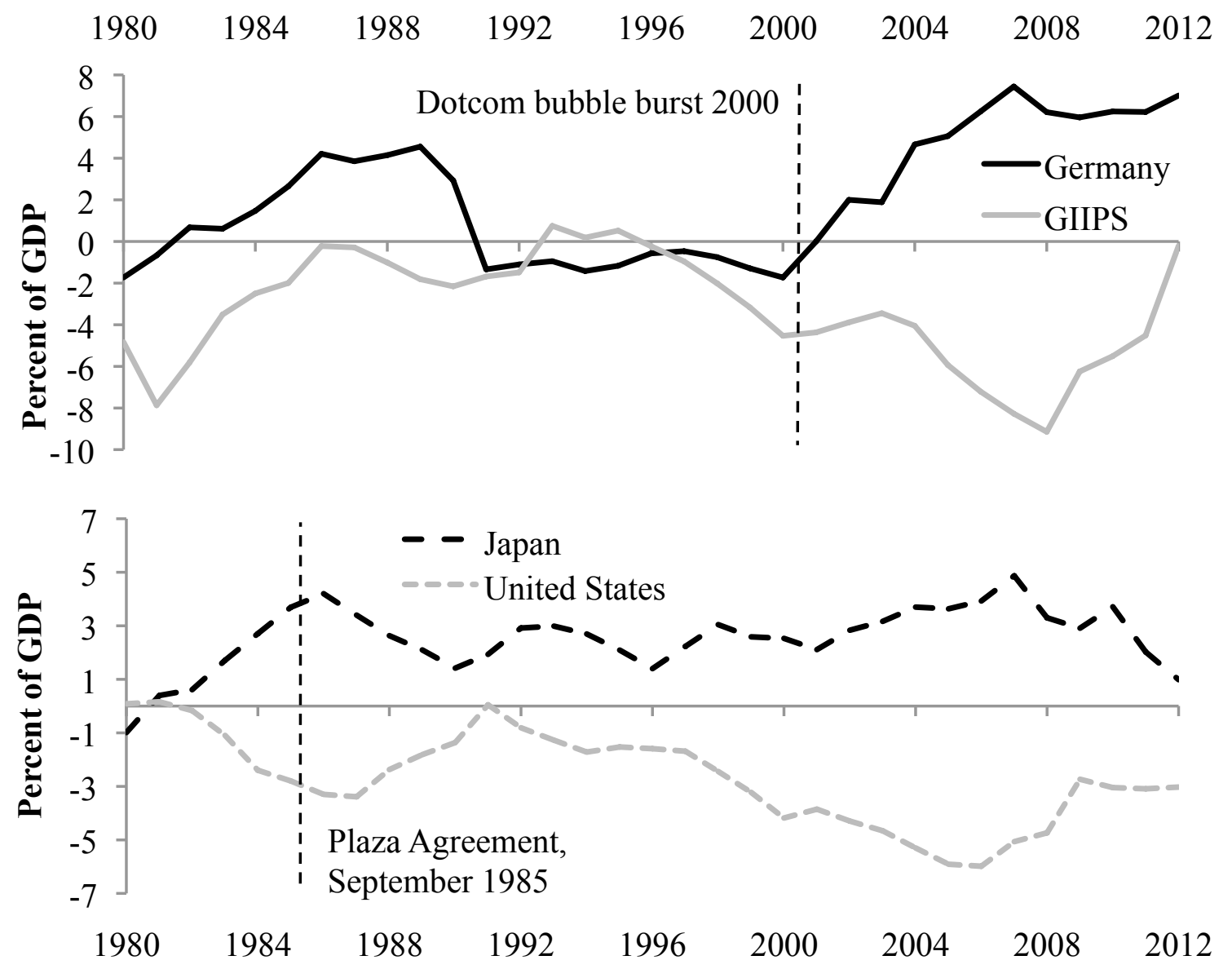

Source: IMF World Economic Outlook. GIIPS is Greece, Ireland, Italy, Portugal and Spain (arithmetic average).

At the European periphery buoyant capital inflows and historically low interest rates provided an incentive for rising government spending and proliferating wage policies in the public and

4 During the restructuring process investment declined. The wage policies, which pursued similar paths in the public and the private sector, can be seen as link between the austerity measures in the public and the private sector. 
private sectors (for instance Greece and Portugal). In other countries buoyant capital inflows from northern European countries with high saving rates, which assumed de facto the role of an expansionary monetary policy, triggered real estate and financial market booms (for instance Spain, Ireland and Cyprus). Similarly to Japan during the second half of the 1980s, rising government expenditure and wealth effects of rising asset prices contributed to rising consumption (Abad et al. 2013). Depending on if the speculation and consumption booms generated government revenues beyond rising government expenditure the debt levels of the later crisis countries increased (for instance Greece and Porutgal) or decreased (for instance Ireland and Spain).

Figure 2 compares the development of stock prices in response to interest cuts in Japan and Europe. In Japan the interest rate cuts starting in 1986 went along with sharply increasing stock prices without major lag. In Europe, the stock market response to interest rate cuts starting in 2001 was delayed. After the dotcom shock, stock prices continued to decline until 2003 and rose sharply since then. The stock market booms were more pronounced in the later crisis countries (for instance Greece and Ireland) compared to Germany (Figure 2). German stock prices were dragged down by the consolidation efforts of German enterprises and austerity in public spending, but stimulated by the improving performance of German export enterprises and financial institutions. Country-specific real estate booms emerged in different parts of Europe, being particularly pronounced in Spain and Ireland (but also Central and Eastern Europe), while real estate prices in Germany remained widely flat. ${ }^{5}$

The current account surplus of Japan declined during the speculation boom on stock and real estate markets in the second half of the 1980s as domestic demand was stimulated by rising government expenditure and positive wealth effects of rising asset prices. But the Japanese current account position returned towards the pre-1985 level after the burst of the bubble in December 1989 (Figure 3). In Europe different monetary and fiscal policy mixes led to sharply diverging intra-European current account balances starting from 2001 (Figure 3). In the north of the European (Monetary) Union (in particular in Germany) the current account balances improved on the back of public austerity, staggering investment and sluggish growth. In the south current account balances of the booming countries of the European Monetary Union (EMU) as well as of many European countries outside EMU (for instance

5 Germany had experienced a real estate boom in Eastern Germany during the unification boom. The bursting of the Eastern German real estate bubble had led to a significant decline of Eastern German real estate prices and balance sheet recessions in particular for Western German private investors. 
Iceland, Bulgaria and the Baltics) dramatically turned negative on the back of overconsumption and/or speculation booms. Despite strongly diverging intra-euro area current account balances the current account balance of the euro area as a whole (Europe as a whole) remained widely balanced.

\section{Trigger of the Crisis and Crisis Therapies}

In Japan, the Bank of Japan recognized that the credit driven stock and real estate boom, which was transmitted with a lag via wealth effects into a consumption boom and rising inflation, was not sustainable. Starting from 1988 the Bank of Japan lifted interest rates to deflate the bubble (Figure 1). Real estate transactions were tried to be hampered by tighter regulations and higher taxes. ${ }^{6}$ In December 1989 the stock market bubble burst (Figure 2), 1991 the upward trend on real estate markets was reversed. ${ }^{7}$ The Bank of Japan kept monetary conditions tight until 1991 (Figure 1) to ensure a consolidation of credit to the private sector in the balance sheets of private commercial banks. Both the restrictive monetary policy in response to the bubble as well as the restrictive monetary policy stance during the first phase of the post-bubble recession were ex post seen as monetary policy mistakes (Posen 2000). Bernanke (2000) dubbed the Japanese post-bubble stagnation of the 1990s as ,self-induced paralysis”, which could have been avoided by decisive policy action and „unconventional measures" such as outright purchases of government bonds and/or discretionary currency depreciation.

In Europe, the financial, government debt and economic crisis was initiated by the monetary tightening starting from end of 2005 (Figure 1), which followed the monetary tightening by the US Federal Reserve. The outbreak of the US subprime crisis in August 2007 can be seen as the final trigger as the risk assessment on global financial markets, in particular concerning international lending, changed. The possible emergence of financial market bubbles was not regarded as a motivation for the monetary tightening by the European Central Bank. Rather the concern about rising inflation had grown. Similarly as in Japan, inflationary pressure had for a long time in average not emerged in the European Monetary Union. Fiscal and wage

Currently the Chinese government tries to cool down the real estate boom in China by similar measures.

Since then real estate prices have continued to fall even below the pre-1985 level. 
austerity in Germany had kept average EMU inflation low, although inflation rates in the later crisis countries had grown substantially beyond the $2 \%$ benchmark. In contrast to Japan the European Central Bank did not lift the interest rate up to the pre-boom level (Figure 1).

In contrast to Bank of Japan the characteristics of the crisis in Europe are - as the pre-crisis boom - heterogeneous. The countries at the periphery of the European (Monetary) Union which have experienced similar to Japan in the 1980s a pronounced boom-and-bust cycle after the turn of the millennium - go through a severe recession. Germany - which has experienced a severe phase of austerity before the crisis - is blessed by robust economic performance and a continuing decline in unemployment. The pre-crisis reforms, which have resulted in low unit labor costs and comparatively sound government budget balances are the basis for Germany's growing role of an insular growth engine in Europe. ${ }^{8}$

\section{Interest Rate Cuts and Unconventional Monetary Policy}

In the early years of the crisis the Bank of Japan cut interest rates hesitantly. When the crisis persisted interst rates were cut more decisively and reached a level of $0.5 \%$ in the mid $1990 \mathrm{~s}$ (Figure 1) during a period of painful appreciation pressure on the Japanese yen. ${ }^{9}$ Money market interest rates converged towards zero during the Japanese financial crisis in 1998/99 about ten years after the bursting of the bubble on the stock market. Because the zero interest rate policy could not reanimate the Japanese economy, unconventional monetary policy measures followed to support fragile financial institutions, weak small and medium enterprises as well as large export enterprises by preventing further yen appreciation.

In the late 1990s, the Bank of Japan pathed the way into "unconventional monetary policy", which went far beyond the textbook monetary policy pattern (Posen 2000, Ueda 2012, Iwata and Takenaka 2011). The Bank of Japan balance sheet was gradually inflated by purchases of stocks, bonds, government bonds etc. (Bernanke 2000). Figure 4 shows as a proxy for the scope of unconventional monetary policy measures the Bank of Japans' monetary base as a share of GDP: It increased from about $10 \%$ in 1989 to about $25 \%$ in 2012. In periods of economic recovery the exit from this very expansionary monetary policy was occasionally

\footnotetext{
8 The extensive restructuring processes in the public and the private sectors during the second half of the 1990s and after the turn of the millennium can be also seen as the main driving force of fast rising German net capital exports and current account surpluses after 2001 (Abad et al. 2013).

9 The Japanese yen got under strong appreciation pressure, because the Federal Reserve kept interest rates very low for verg long after the bursting of the dotcom bubble.
} 
attempted, but interrupted because of reemerging financial fragility and reemerging appreciation pressure on the Japanese yen. Figure 5 shows how in the years 2000 and 2006 to 2008 short-term interest rates were temporarily slightly lifted and then lowered again. The temporary increases in short-term interest rates are reflected in respective declines in the monetary base (Figure 4).

\section{Figure 4: Monetary Base as Percent of GDP}

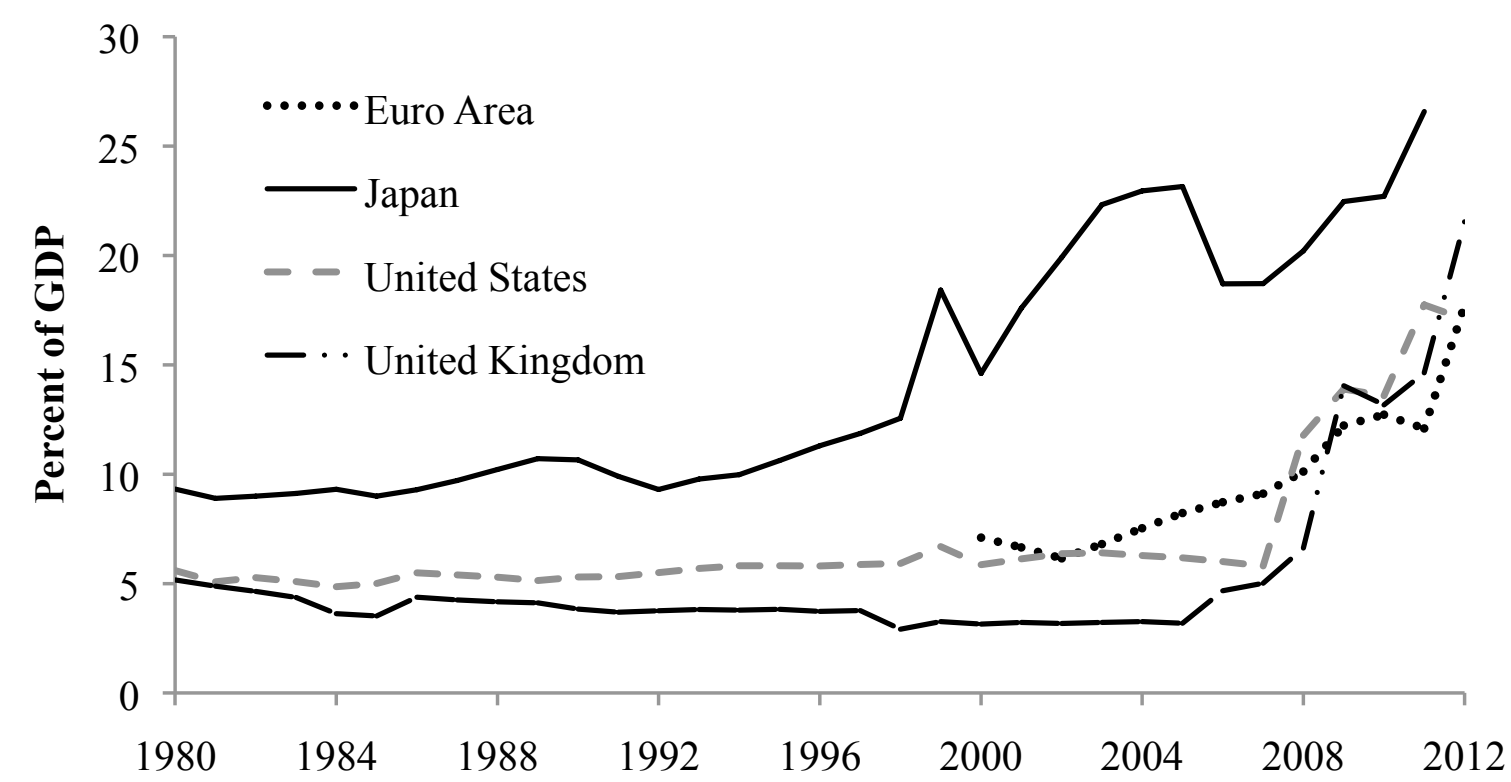

Source: IMF International Financial Statistics and World Economic Outlook, European Central Bank and Eurostat, via Datastream.

In Europe, despite objections from Germany (where high private savings of the household sector underpin a widespread concern about inflation) the European Central Bank cut interest rates faster towards zero and stepped over much earlier to unconventional monetary policy measures than the Bank of Japan in response to the bursting bubble. Like during the period prior to the outbreak of the crisis, the one-size monetary policy does not fit all. For the European crisis countries the harsh monetary expansion seems appropriate as deeper financial and economic meltdowns are prevented. For Germany, like in Japan during the second half of the 1980sthe current monetary policy stance seems too loose. A real estate and stock market bubble seems to be triggered. Real estate prices in metropolitan areas have started to hike. Stock prices have already reached historical hights (Figure 2). 
Despite gradually rising government debt to unprecedented high levels, risk premiums on Japanese government bonds never became visible. If short-term interest rates are depressed (close to) zero indefinitely, this pulls down long-term interest rates, because long-term interest rates are equivalent to the expected future short-term interest rates plus a liquidity premium. The clearly intertwined downward trend of short- and long-term rates in Japan towards zero is shown in Figure $5 .{ }^{10}$ This implies that linked to the monetary expansion in form of interest rate cuts and unconventional monetary policy measures (including government bond purchases) the Bank of Japan provided an implicit insurance mechanism against outright government default.

\section{Figure 5: Money Market Rates and 10-Year Government Bonds Yields in Japan}

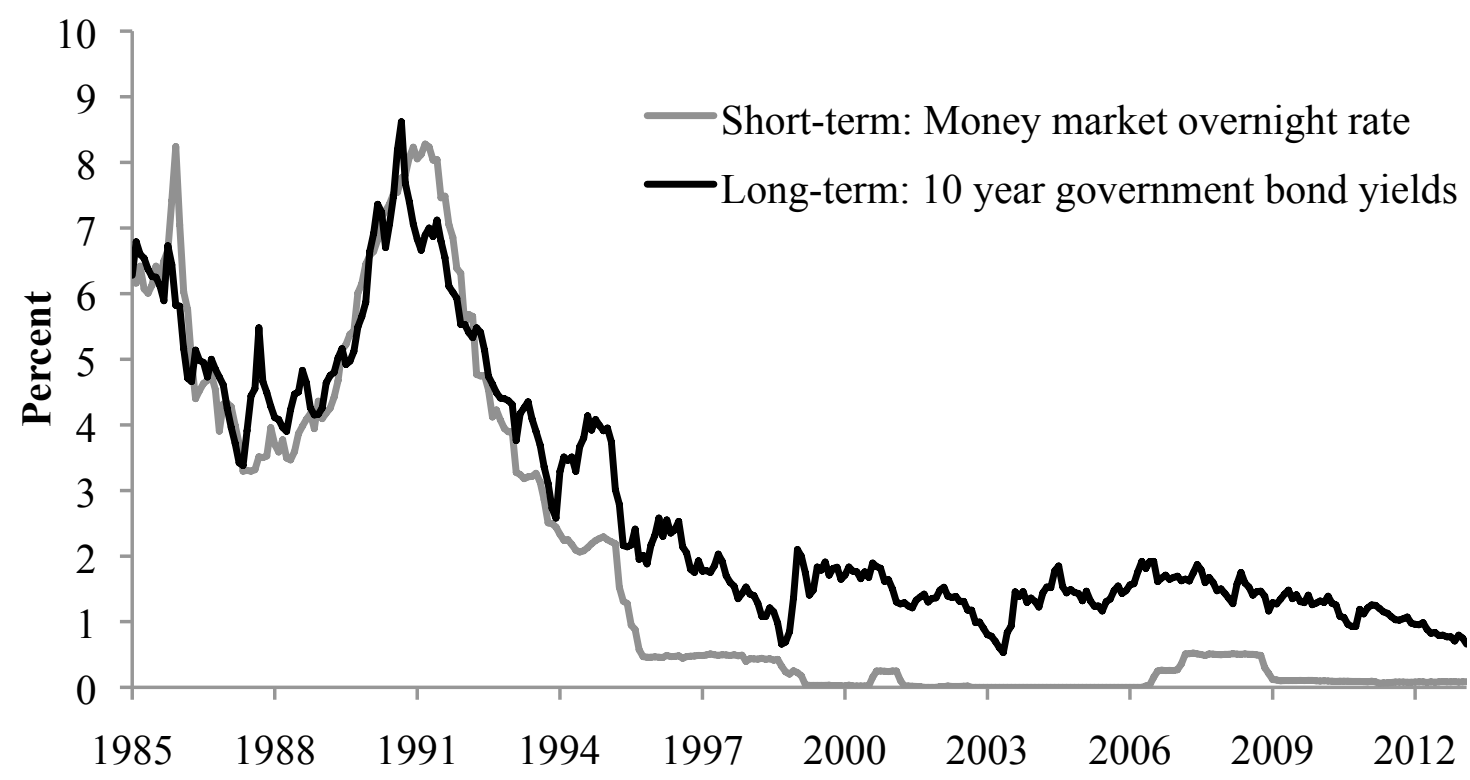

Source: IMF International Financial Statistics, via Datastream.

In contrast to Japan, at the beginning of the crisis the European crisis countries could not hope for a direct support of the European Central Bank as they only participated with a minority in the European Central Bank's governing council. This led in contrast to Japan to dramatic hikes of risk premiums on the crisis countries' government bonds. Only the gradual implementation of rescue mechanisms by EU and IMF as well as in particular outright

10 Note that this downward trend of short-term and long-term interest rates is also clearly correlated with the downward trend of US short-term and long-term interest rates. 
purchases of crisis countries' government bonds in the secondary sovereign bond market by the European Central Bank initiated the reduction of interest rate spreads versus German government bonds.

\section{Recapitalization of Banks}

Ueda (2012) sees the retarded recapitalization of Japanese banks as the main reason for the delayed recovery from the balance sheet recession. The recapitalization of the Japanese banks was postponed until the late 1990s after the Japanese financial crisis had substantially worsened the bad loan problem. ${ }^{11}$ Before the government had urged stronger banks to take over non-profitable banks what was dubbed "convoy approach" (Shimizu 2000). In 1998 the Financial Reconstruction Law ${ }^{12}$ was put in place that obligated banks to publish detailed information on their bad loans. The new law also allowed for the nationalization of banks. In the same year the Early Strenghtening Law ${ }^{13}$ got into force that allowed the recapitalization of banks. In March 1999 all big banks were recapitalized with an amount equivalent to 80 billion euros. Up to March 2001169 credit institutions were nationalized with a sum equivalent to 170 billion euros.

The notion that the too late recapitalization of commercial banks led to an unnecessary prolangation of the Japanese crisis contributed to the a faster recapitalization of European banks in distress to prevent a credit crunch resulting from falling asset prices and shrinking equity ratios. In Germany, at the very beginning of the crisis takeovers took place in a form of a Japanese type convoy system (IKB, SachsenLB). Then, commercial banks were recapitalized (Commerzbank), nationalized (Hypo Real Estate), or closed down (WestLB). In contrast to Japan where bancruptcies of financial institutions such as Sanyo Securities, Yamaichi Shoken, Long-Term Credit Bank were tolerated, this was not the case in Europe. In particular, the Emergency Liqudity Assistance of the national central banks provided liquidity for eased collateral conditions to commercial banks in distress in the European crisis countries.

11 Up to 1997/98 Japanese financial crisis Japanese banks could (partially) compensate their losses from domestic asset price deflation by expanding international credit, in particular to the booming Southeast Asian countries such as Indonesia, Malaysia, Philippines, South Korea and Thailand. When the Southeast Asian economic miracle came to an end in 1997 with the outbreak of the Asian crisis, Japanese financial institutions realized new losses, which triggered the Japanese financial crisis.

12 金融機能の再生のための緊急措置に関する法律

13 金融機能の早期健全化のための緊急措置に関する法 


\section{Zombie Lending and Evergreening}

Caballero, Hoshi and Kashyab (2008) dubed Japanese banks "zombie banks" that depend on public subsidies, i.e. the steady provision of very low-cost liquidity by the central bank. This implies that the zero-interest rate liquidity provision changed incentives for restructuring to become profitable again in both the financial and enterprise sector. Caballero, Hoshi and Kashyab (2008: 1) stress the detrimental impact of zombie lending on the enterprise sector: "We confirm that zombie dominated industries exhibit more depressed job creation and destruction, and lower productivity." With the cost of money being (close to) zero, banks became tempted to roll over loans to enterprises to avoid bad loans from becoming visible, although the enterprises were not profitable any more.

Sekina, Kobayashi and Saita (2003) model forbearence lending: credit provision to the private sector becomes delinked from the profitability of investment projects, rather becoming path dependent. This implies that low profitability of the banking sector is rolled over to the enterprise sector, with the marginal efficiency of investment declining. Peek und Rosengren (2005) identify a misallocation of capital in the credit sector, which keeps enterprises with gloomy business perspectives alive (,evergreening“ ${ }^{14}$. Since 2012, a Law on Comprehensive Measures to Facilitate the Financing for Small and Medium-Sized Enterprises ${ }^{15}$ forces banks to continue credit provision to small and medium enterprises at low costs.

\section{Keynesian Spending Programs}

After the bursting of the Japanese bubble economy enterprises faced painful losses on their assets, what made them to reduce investment due to the negative wealth effect of declining assets prices. This forced the public sector to smooth out the resulting negative business cycle

14 In practice the insolvency law did not work, as large banks were considered to be too big to fail. The de facto missing legal framework became an impediment for market-based solutions of the financial crisis. The reforms of the Koizumi government of the insolvency and labor laws were only partially successful and were reversed in 2009 when the Democratic Party of Japan (DPJ) took over the government. The reform of the insolvency and labor laws are an important challenge for the new Abe government.

15 中小企業者等に対する金融の円滑化を図るための臨時措置に関する法律の一部を改正する法律. The law is seen as the result of the lost elections of the primeminister Koizumi in the year 2009, which can be interpreted as the voters' response to Koizumis reform efforts. As the law did not lead to the expected results it is to be abolished under the Abe government, although the small and medium enterprises provide political support for the Liberal Democratic Party (LDP). 
effect by providing stimulus via credit financed public spending. The Japanese government implemented several Keynesian spending programs to stabilize the Japanese economy in particular outside the economic centers Tokyo and Kansai. As the public spending programs were focused on public infrastructure projects such as highways, bridges, bullet-train tracks and public buildings the construction industry experienced an extraordinary stimulus (Yoshino und Mizoguchi 2011). Given the continuous growth of public demand, the marginal efficiency of public investment can be assumed to have decreased over time. Driven by the costs of public spending programs, losses of tax revenues due to the sustained recession and the costs of commercial bank recapitalization the gross public debt of Japan climbed to a historical high of $235 \%$ des GDP in the year 2012 as shown in Figure $6 .{ }^{16}$

\section{Figure 6: Gross Public Debt as a Share of GDP}

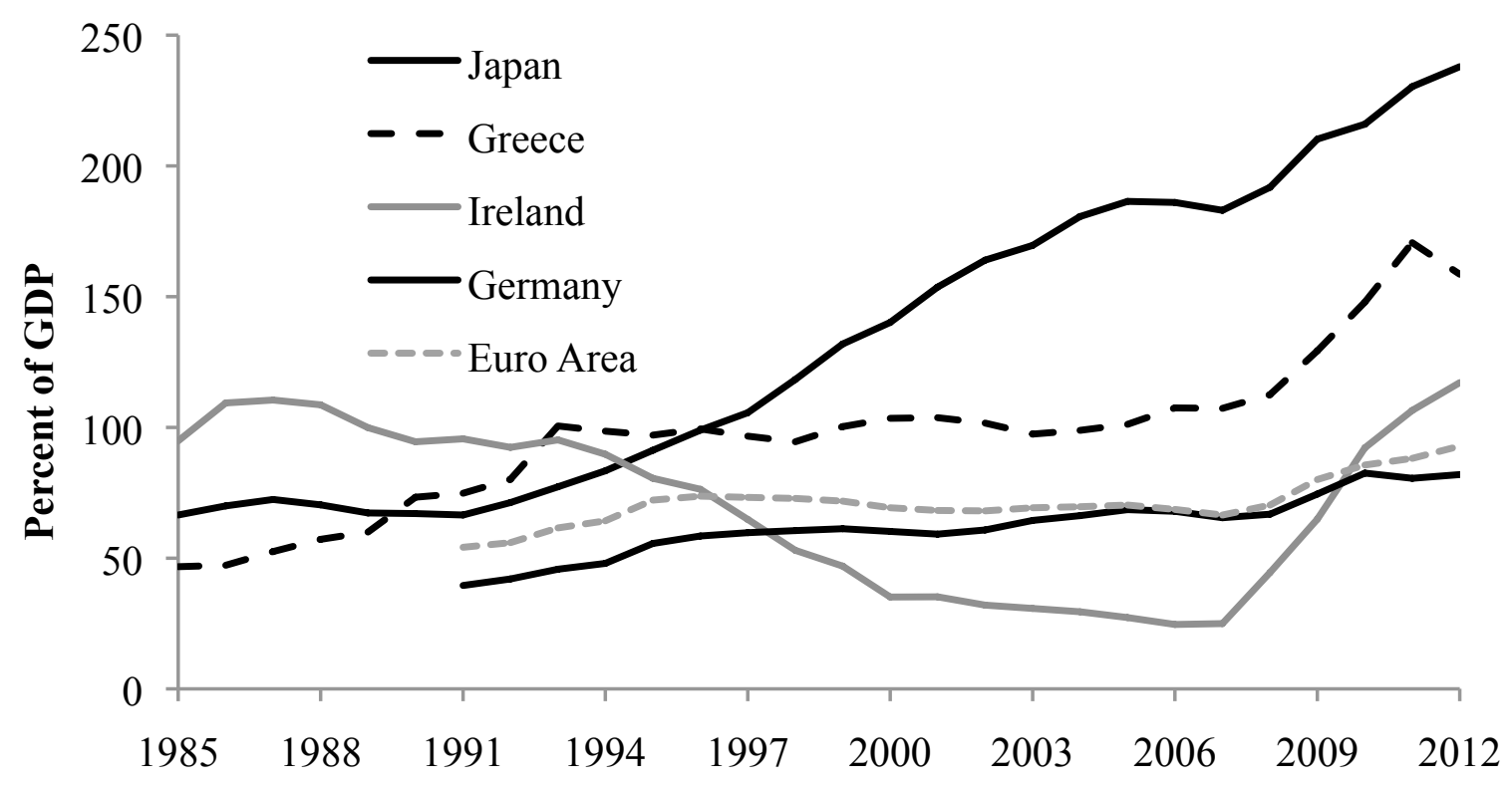

Source: IMF World Economic Outlook, via Datastream.

While the credit volume of the banking sector to enterprises and households declined - linked to Keynesian public economic stimulus programs and declining tax revenues - the public demand for credit increased (Yoshino 2013). As a result in the aggregated balance sheet of the private banking sector credit to the private sector has been stepwise substituted by credit to

16 Note that net public debt which accounts for the large foreign assets held by the Japanese Ministry of Finance linked to massive foreign exchange intervention against yen appreciation is substantially lower, at about $140 \%$ of GDP. 
the public sector. As shown in Figure 7 between 2001 and 2012 claims on the private sector as a share of overall assets declined from about $77 \%$ to $65 \%$. During the same time period claims on the public sector increased from about $23 \%$ to about $34 \%$.

Figure 7: Claims of Japanese Banking Sector on Public and Private Sector

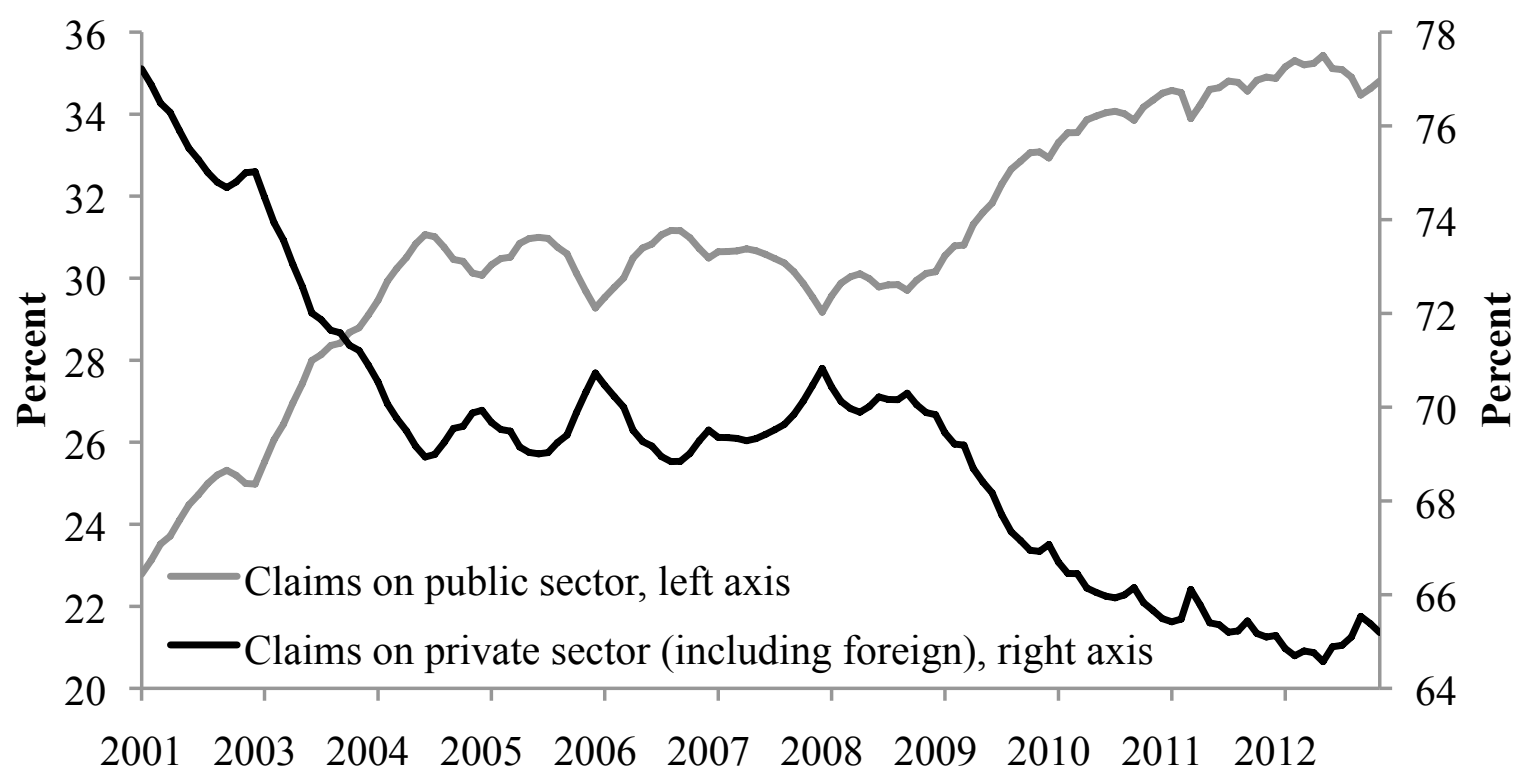

Source: IMF International Financial Statistics, via Datastream. Shares of total assets.

In Europe, there are restrictions to Keynesian spending programs, as govenrment debt in most EU member states has climbed to historically high levels, far above the limits of the tightened stability and growth pact. This shifts, however, the responsibility for macroeconomic stabilization back to structural reforms or - alternatively - to the European Central Bank, which is urged into easier monetary conditions to keep government debt under control. In the euro area the monetary base as a share of GDP increased substantially and faster than in Japan, although the degree of base money expansion is still lower (Figure 4). Figure 6 shows nevertheless a substantial increase of public debt of European countries since the start of the crisis. In Germany, where the economic performance is sound and where - linked to the low interest rate policy of the European Central Bank and the function of Germany as a safe haven in Europe - interest payments on government debt have further declined public debt is remaining contained. Yet, the rising liabilities for the rescue measures of a rising number of crisis countries has increased the implicit liabilies for the German government. 
In the European Monetary Union the effectiveness of any attempts to limit government debt might be undermined as large-scale rescue packages and risks accumulated in the balance sheet of the European Central Bank have inflated the implicit government debt of the rescuing countries far beyond the institutional limits of the Maastricht Treaty. In addition, the low interest rates guaranteed by the European Central Bank provide an incentive to further increase government debt. Nevertheless, the framework of the European Monetary Union to control government debt based on institutionalized rules serves as a role model for Japan in its attempts to keep public debt under control (Yoshino 2011).

\section{Economic Consequences of Japanese Crisis Therapies}

The economic consequences of the crisis therapy in Japan, which should provide a role model for economic policy decision making in Europe, are linked to unintended side effects of rescue measures beyond financial market stabilization, the collapse of financial intermediation, the hysteresis of the low-interest rate trap, the erosion of the allocation and signaling function of the interst rate as well as the advent of a quasi-nationalization of aggregate demand.

\section{Unintended Side Effects of Rescue Measures}

The gradual interest cuts of the Bank of Japan since the early 1990s (Figure 1) were linked to continuous net capital outflows (including carry trades ${ }^{17}$ ). In first half of the 1990s Japanese banks could compensate for their losses from the bursting Japanese bubble economy by refinancing at very cheap conditions in Japan and expanding credit to the fast growing Southeast Asian economies. Japanese export enterprises participated in the Southeast Asian boom via rising demand from these countries and by building up subsidiaries with low labour

17 Capital could be raised at very low interest rates in Japan and could be invested in countries with higher interest rate levels (often emerging market economies such as New Zealand or Russia). The returns from positive interest rate spreads were threatened to be turned negative by potential yen appreciatoin versus the investment currencies. This risk was mediated by foreign exchange intervention against yen apprecation and Bank of Japan interest rate cuts and quantitative easing which softened yen appreciation pressure. This made carry trades a lucrative source of income. 
cost. When the Southeast Asian boom turned sour in 1997, both Japanese banks and Japanese export enterprises suffered from new losses, which became reflected in a significant decline of prices on the Tokyo stock exchange, the Japanese financial crisis, and the collapse of large financial institutions. Since then, foreign financial market shocks have negative feedback effects on Japans' economic recovery contributing to the continuous decline of stock prices as shown in Figure 2.

Similar negative feedback effects on the private sector are less likely in Europe, as the assets of German and other European banks in the crisis countries were to a substantial degree nationalized in the course of the rescue measures. On the other side, while the current account deficits of the crisis countries are stepwise reduced towards zero on the back of extensive austerity programs, the German current account surplus persists (Figure 3). This implies that German net capital exports are redirected to the third countries (outside the euro area) where new risks might be accumulated, similar to Japanese banks during the Southeast Asian boom.

The high and - based on sustained current account surpluses - ever growing net international assets of the Japanese private sector, made enterprises, households and financial institutions vulnerable for the appreication of the Japanese yen. As Japans international assets are denominated in foreign currency (mostly US dollars), a strong appreciation of the Japanese yen against the US dollar not only slows down Japanese exports, which remain the most important pillar of growth. Yen appreciation also melts off net international assets in terms of domestic currency (McKinnon und Schnabl 2004). The outcome is a negative balance sheet effect, to which financial institutions may respond by reducing credit to private sector. For this reason exchange rate stability against the dollar became a pivotal pillar for financial and macroeconomic stability in Japan (Goyal und McKinnon 2003). This contributes to the persistence of the zero interest rate policy and quantitative easing, as both monetary policy measures aim to dampen the appreciation pressure on the Japanse yen.

For Europe the net international asset position is in contrast to Japan of minor concern for two reasons. First, the current account position and therefore the net international investment position of the European (Monatary) Union as a whole is widely balanced. From this perspective the European crisis is more a question of intra-European redistribution. Second, the foreign assets and/or liabilities of euro area countries can be assumed to be to a larger extend denominated in euros, i.e. in domestic currency. This makes the financial sectors less vulnerable to euro appreciation in the face of monetary expansion in the US. Nevertheless, as 
the appreciation of the euro against the dollar is a major concern for the export sectors of the former weak currency and now crisis countries, their competitiveness can be seen as a major determinant of the European Central Banks' interest rate decisions.

\section{The Collapse of Financial Intermediation}

Both in Japan and in the European Monetary Union the low interest rate policies provoked the collapse of money markets with tradning volumes declining dramatically. Given rising perceived risk of interbank lending, liquidity provisions among commercial banks became substituted by liquidity provision of central banks to commercial banks. McKinnon (2012) explains how zero interest rate policies undermine financial intermediation on money markets as large non-financial corporations tend to finance directly via issuing commercial bills to savers. This leaves (in particular smaller) banks with a riskier portfolio of loans to small and medium enterprises, thereby facing a higher capital constraint. Banks have to hold more capital for a rising average default risk and/or to reduce the outstanding amount of credit to small and medium enterprises. ${ }^{18}$ With yields on money markets having declined to very low levels potential lenders are disinclined to lend for a derisory yield. Finanical institutions will rather prefer to deposit their excess cash at the central bank. If on the money market any financial institution would bet for funds for a substantially higher rate than the prevailing money market rate this would signal high risk, impeding it even more from receiving credit from other private financial institutions.

Furthermore, the zero interest rate policy contributed to a decline of bank-based lending to the private sector (credit crunch) since the Japanese financial crisis (Figure 7). The Japanese credit crunch has been argued to either driven by the necessary consolidation of the commercial bank balance sheets or by the shrinking credit demand of the enterprise sector (Ishikawa und Tsutsui 2005). Proponents of a supply driven credit crunch hypothesis see the asset price deflation as the origin of shrinking credit provision to the private sector (Posen 2000). As assets prices fall, the equity of financial institutions is melting off what forces financial institutions not to renew outstanding credit to enterprises. Bancruptcies in the enterprise sector cause new bad loans for financial institutions, which have to further tighten

18 The credit provision of commercial banks to small and medium enterprises declined from 347 trillion yen in 1993 to 245 trillion yen in 2011. 
their credit conditions. ${ }^{19}$ Monetary expansion and recapitalization of banks was seen as an effetive remedy against this supply driven credit crunch (Posen 2000, Bernanke 2000). ${ }^{20}$

\section{Figure 7: Interest Rates, Real Growth and Credit Growth in Japan}

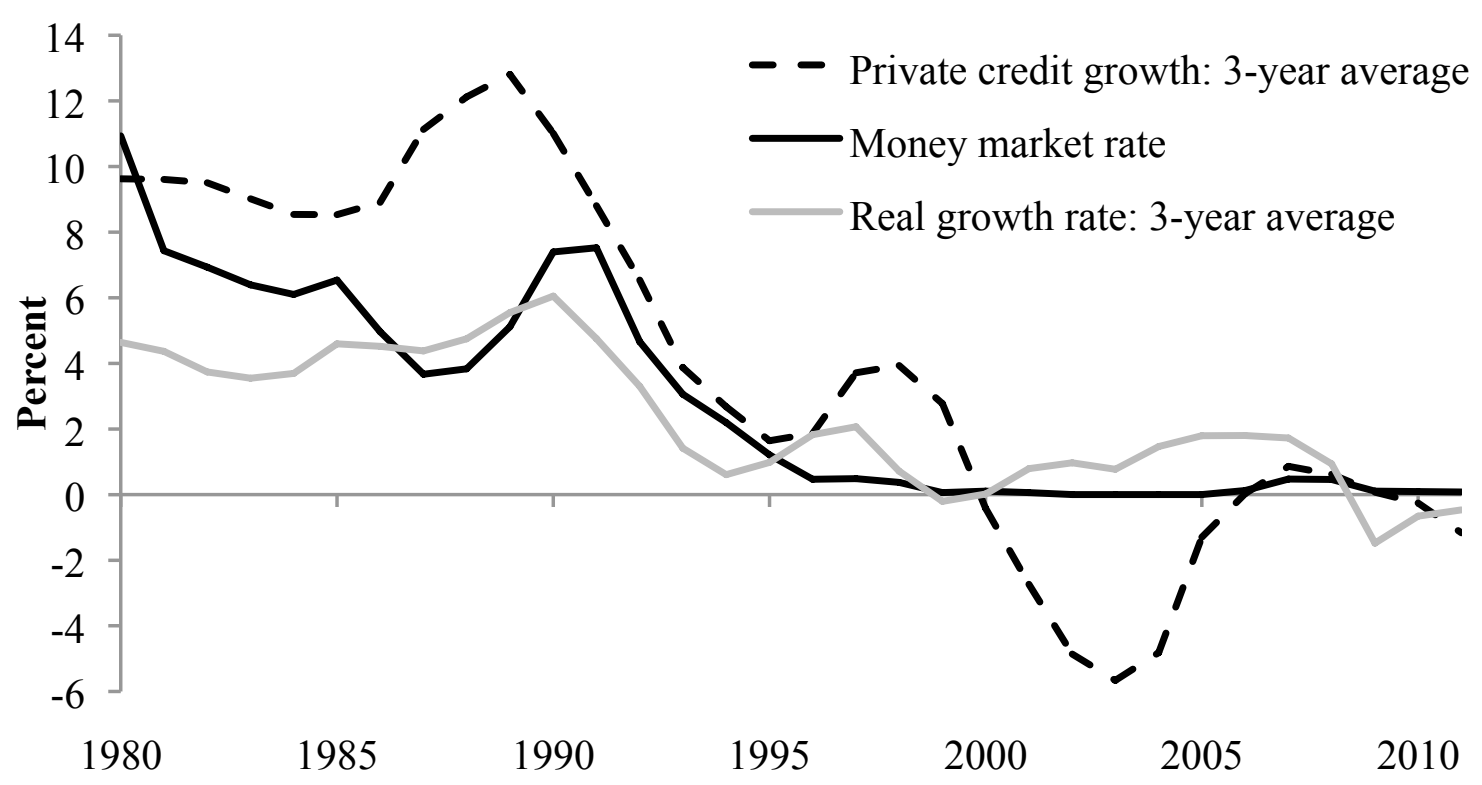

Source: IMF International Financial Statistics, via Datastream. Claims on private sector refer to commercial banks.

The demand-sided credit crunch hypothesis stresses the negative wealth effect of asset price deflation. As enterprises suffer from revaluation losses on their assets they reduce investment to consolidate their balance sheets. The credit opportunities of financial institutions become beclouded. This forces them to further tighten credit conditions and/or to sell stocks and real estate, what leads to a further decline of asset prices. Furthermore, the substantial decline in interest rates improved the financing conditions for large enterprises and therefore contributed

19 Fisher (1933) formed a debt deflation theory for the Great Depression with respect to the impact of deflation on real debt. In contrast to the Great Depression, however, a sustained process of consumer price deflation did not set in in Japan. Although during some periods prices moderately declined, since the bursting of the bubble economy the consumer price level has remained widely unchanged. Periods of deflation during the Japanese post-bubble recession have to be seen in the context of the low-interest rate policy and internationally integrated capital markets: As long as the nominal and the real interest in the US were positive, given a zero nominal interest rate in Japan, the inflation rate had to fall below zero to ensure that in both Japan and the US the same positive real interest rate prevailed. Given that US nominal interest rates were higher than in Japan, this also implied based on the open interest rate parity persistant appreciation expectations of the yen versus the dollar (as it was the case during most of the post-bubble recession) (Goyal and McKinnon 2001).

20 In effect the money multiplier defined as the ratio between a broader measure of money supply (for instance M2) and the monetary base declined (Ueda 2012: 193-196). 
to a demand-sided credit crunch, because improved financing conditions for enterprises increased aggregated enterprise saving. Figure 8 shows how the decline in interest rates after the burst of bubble economy went along with a transformation of the non-financial corporations sector from a net debtor into a net saver. The financial surplus (net saving) of non-financial corporations increased from about $-10 \%$ of GDP in 1989 to $+5 \%$ in 2011 . $^{21}$ This allowed enterprises to close credit lines with commercial banks. ${ }^{22}$ In the case of a demandsided credit crunch, the ever-rising liquidity provision by the central bank to commercial banks as indicated in Figure 5 would not be an effective tool to cure the crisis.

Figure 8: Japan: Financial Surplus or Deficit by Sector

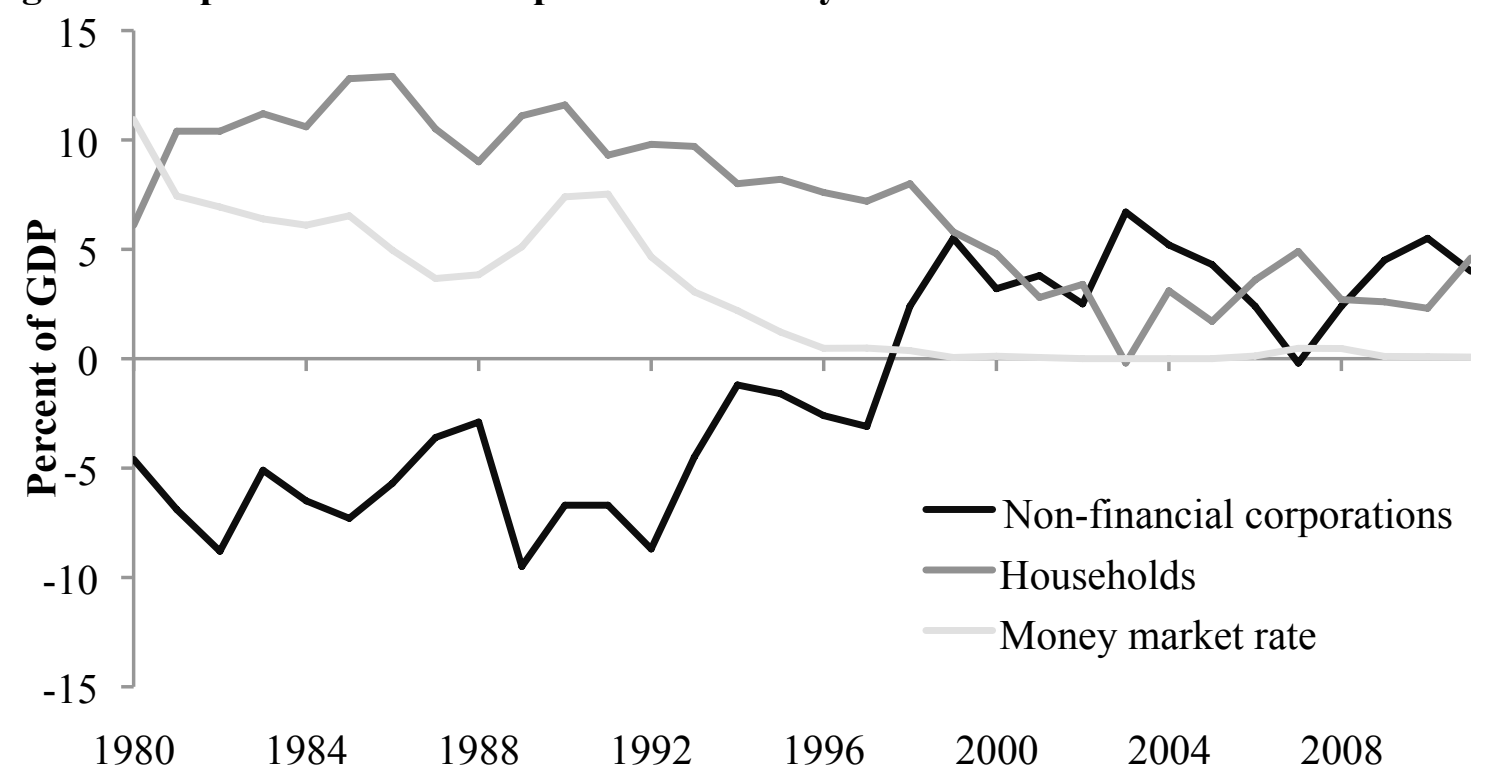

Source: Cabinet Office, Government of Japan.

The credit crunch, which has been obversed in Japan (Figure 7), is in Europe limited to the crisis countries suffering from capital flight. The credit crunch became virulent as banks from non-crisis countries started to close their credit lines. The deflationary effects of tightening credit conditions became attenuated by credit provision at eased collateral conditions by the national central banks in form of Emergency Liquidity Assistance. The national central banks

21 During the same time period household saving declined from about $10 \%$ of GDP in 1990 to about $4.5 \%$ of GDP in 2011.

22 Some large enterprises in Germany such as Siemens and BMW have in addition got direct access to low-cost central bank financing via own financial subsidiaries. This is a sigficant competitive advantage versus smaller enterprises, which have to rely on financing by the banking sector. 
in crisis contries became to be refinanced by the European System of Central Banks via the TARGET2 payment system, which took over a form of unlimited supranational liquidity/credit provision (Sinn and Wollmershäuser 2012). In Germany, sufficient liquidity is available in the commerical bank sector, which continues to reduce credit lines to the crisis countries. Given rising deposits of German commercial banks at the central bank the Deutsche Bundesbank is transfromed from a central bank, which supplies credit to the domestic banking system, into a central bank, which absorbs liquidity from the domestic banking system.

European banks were recapitalized faster than Japanese banks to prevent a similar balance sheet recession. Polleit (2011) provides an explanation, why in the face of a balance sheet recession the recapitalization of banks is not a sufficient condition for a sustained economic recovery. The recapitalization cannot prevent a credit crunch, because credit to the private sector is crowded out by credit to the public sector. Because the governments have no liquidity buffers available, they have to raise the funds, which are needed for the recapitalization by issuing more government debt. The recapitalization of commercial banks allows banks to expand their credit volume, which will - however - be absorbed by an additional credit demand of the government sector. As shown in Figure 8 the recapitalization of Japanese banks at the turn of the millennium was accompanied by an increase of credit to the public sector instead of credit to the private sector (which continued to decrease as a share of overall assets). ${ }^{23}$

Furthermore, zero interest rates per se constitute an impediment for a positive effect of the recapitalization of banks on the credit provision to private enterprises. With interest rates at zero the banks are missing an appropriate benchmark at which an investment project can be assessed to be profitable. From this point of the recapitalization of banks is necessary, but not a sufficient condition for a reanimation of profitable credit to the private sector. The recapitalization of banks would have to be paired with a rising interest rate level. The Japanese credit crunch therefore has to be seen as a crowding out of credit to the private sector by credit to the public sector, which is further enhanced by the Basle requirements on equity ratios and the implicit garantuee on government debt provided by zero interest rate

23 If alternatively the bonds issued by the government to recapitalize commercial banks are bought by the nonbank private sector, the money supply shrinks. In the aggregated balance sheet of the commercial banks private deposits on the liability side of the balance sheet are substituted by rising capital. This is followed by recession and declining prices, what is likely to trigger an additional monetary expansion by the central bank. Government bond purchases of the central bank will put the money supply back to the original level. 
policies.

As in Japan, assessments concerning bad assets in the European banking system (so called stress tests) are sugarcoated by the very expansionary monetary policy in form of a historically low interest rate level, direct emergency liquidity assistance and outright purchases of government bonds. Therefore, as in Japan, in most European countries the number of zombie banks, which have to rely on very-low-cost liquidity injections of the central bank is likely to have significantly increased. In addition, the notion of "zombie states" emerged, i.e. countries, which have to rely on supra-national liquidity provisions (EFSF, ESM, European System of Central Banks, etc.) to safeguard the stability of national financial sectors and government finance. Would the European Central Bank lift the interest rate to a level of - say - three percent (what is still low from a historical perspective), for instance to countersteer a real estate and stock market bubble in Germany, the stress in the European banking systems and crisis countries would substantially grow.

\section{Hysteresis of the Low-Interest Rate Trap}

A second stylized fact of the Japanese macroeconomic crisis management is the interdependence of declining interest rates and rising government debt in form of lock-in effects of interest rate cuts, i.e. the hysteresis of the low-interest rate trap (Schnabl 2012). Figure 5 shows the gradual decline of 10-year government bonds yields, which provided an incentive to increase government debt: With long-term interest rates structurally declining, the level of government debt could be increased without a higher burden of debt service (for instance measured as a share of government expenditure). The Basle requirements concerning capital holdings have been providing an additional incentive for commercial banks to substitute credit to the private sector by government bond purchases and therefore have set in incentive to increase government debt.

Once a very low interest rate level and a very high government debt level are reached shortterm interest rates have to stay (close to) zero, and unconventional monetary policy has to further depress the interest rate at the long end of the yield curve. ${ }^{24}$ Otherwise public finance

24 The current zero interest rate environment in Japan (and other industrializied countries) is often charaterized as liquidity trap (see for instance Krugman 2012). The Keynesian concept of a liquidity trap is, however, different from the Japanese zero-interest rate trap. In the Keynesian liquidity trap expectations that the future interest rates will rise make agents to hold cash (speculative motive). Savings are not invested in bonds and 
would be destabilized. Figure 10 shows a simulation of the interest rate payments as a share of the Japanese central government budget dependent on varying interest rates on Japanese government bonds and varying debt levels. Currently the gross Japanese government debt is about $235 \%$ of GDP and the interest rate on outstanding 10 -year government bonds is in average at around $2 \%$. Interest rate payments as a share of central government expenditure are about $20 \%$. If the average yield on Japanese government bonds would increase to $4 \%$, the interest rate payments as share of the central government budget would increae to $40 \%$. The Japanese government would become financilly restricted. At an interest rate level on 10-year government bonds of $7 \%$ about $70 \%$ ofthe central government budget would have to be spent on debt service. The higher the debt level, the more this effect is reinforced.

\section{Figure 10: Simulation of the Japanese Debt Service Burden}

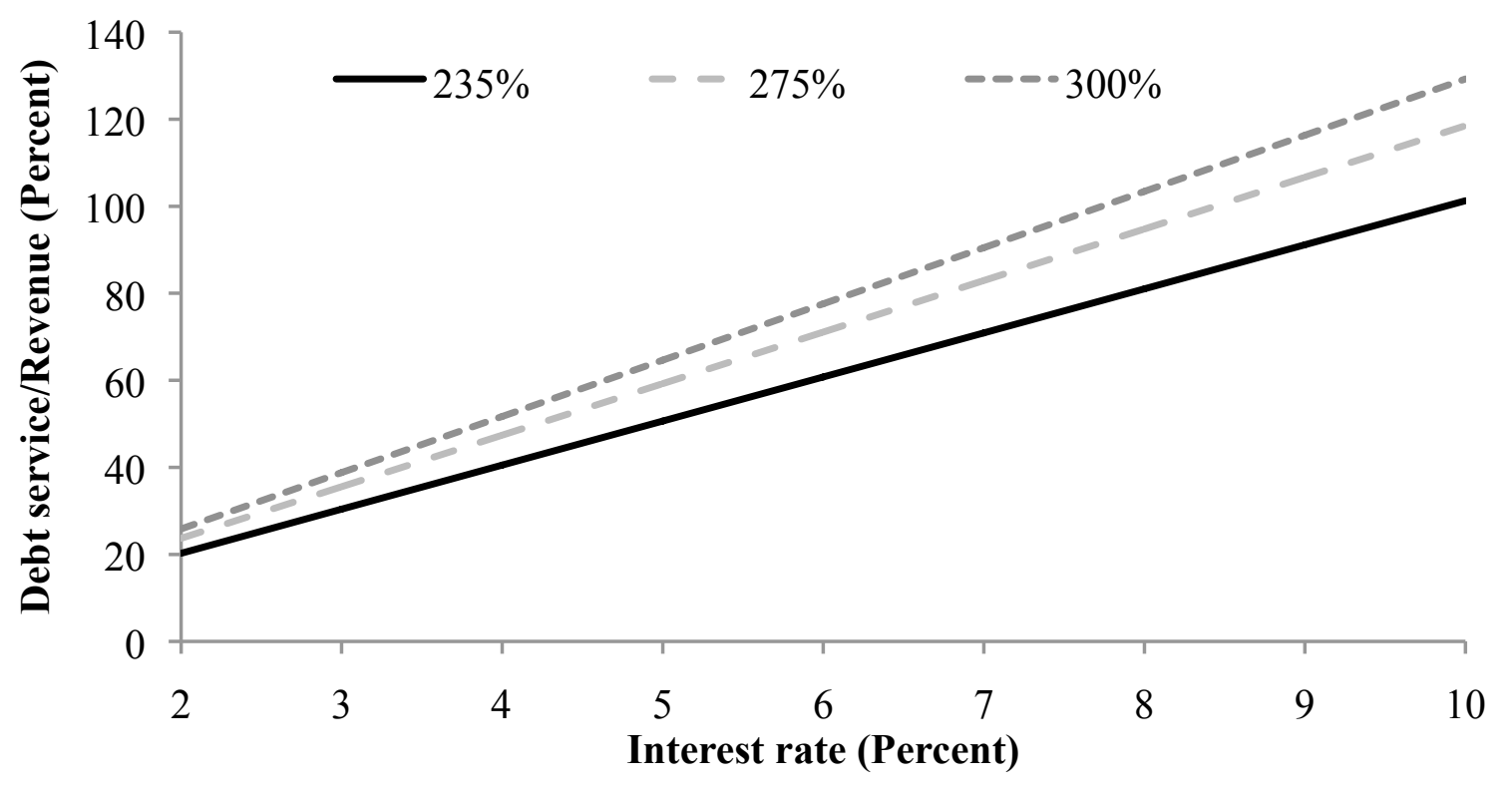

Source: Based on data by Ministry of Finance of Japan, via Datastream.

therefore are not available for investment as opportunity costs of holding money are very low. In the lowinterest rate trap the central bank does not want to increase interest rates, as it fears a negative effect on financial and economic stability. The government exerts pressure on the central bank to keep interest rates low, as it is concerned about rising risk premiums as well as rising costs of debt service and recapitalization of fragile finanical institutions. An increase of interest rates linked to tightened risk perceptions is responded by the central bank with unconventional monetary expansion to keep interest rates low both at the short and the long end of the yield curve. 
The simulation does not include second round effects: For instance, interest increases by the Bank of Japan would be followed by negative business-cycle effets and thereby declining tax revenues and rising instability of the financial sector. If financial institutions would default, the costs of recapitalization would additionally contribute to rising government debt. Furthermore, if interest rates would be lifted, the Bank of Japan itself would suffer from substantial sterilization costs of surplus liquidity in the domestic banking system and from significant revaluation losses on bond holdings in its balance sheet. As the Bank of Japan would become dependent on a recapitalization by the government, it seems de facto have lost its indendence. ${ }^{25}$ For this very reason the political pressure on the Bank of Japan can be assumed to be very strong to further depress interest rates. This very limited degree of monetary policy independence has become most visible under the new primeminister Abe and the new Bank of Japan president Kuroda.

\section{Erosion of Interest Rate Functions and the Nationalization of Demand}

Hayek $(1929,1944)$ has stressed the pivotal role of the interest rate for a stable economic development. If the prime interest rate is kept at or close tozero for too long, not only new boom-and-bust cycles in financial markets (domestic and/or foreign) are encouraged, but also the signalling and allocation function of the interest rate is destroyed. The interest rate has ceded to signal default risk, as the central bank implicitly gurantees government debt as well as the debt of private financial institutions and enterprises. The interest rate does not fulfill its allocation function, which seperates between investment projects with high and low expected returns. Instead, the credit allocation works through zombie banks with path dependence seeming to be the most important determinant of credit allocation. Structural distortions, which have emerged during the boom, are preserved.

Although the expansionary monetary and fiscal policy in the response to the lasting Japanese crisis has prevented an even deeper crisis, it has come along with the gradual decline of private investment both in absolute terms and as a share of GDP. Private investment in Japan has been gradually substituted by public spending. Figure 11 shows the Japanese GDP by expenditure. The share of gross capital formation out of GDP was 32\% in the 1990, and has

25 Carpenter et al. (2012) provide a detailed insight into the impact of an exit from low interest rate policy and quantitative easing on the equity of the Federal Reserve Bank. 
declined to $20 \%$ in the year 2011. During the same time period the share of government spending increased from $13 \%$ to $21 \%$ of GDP.

The projection of Bernanke (2000) that interest rate cuts and Keynesian economic stimulus would revive Japanese growth has not been fulfilled. As shown in Figure 6 the real growth rate in Japan has fallen together with the interest rate. This can be interpreted as a gradual decline of the marginal efficiency of investment as the interest rate benchmark for investment projects has gradually declined. Whereas real growth rates since the year 1990 still add up to an yearly average of $1 \%$, the stock price index as indicator for the performance of the Japanese economy has with today 14.000 points $^{26}$ declined even below the level before the start of the Japanese bubble economy in 1985 (Figure 2). The growth perspectives remain gloomy because the US and Europe as important target regions of Japanese exports have gone through similar boom-and-bust-cycles and are similarly facing declining growth momentum. Chinese growth as an important source of demand for Japanese products is slowing down as well.

\section{Figure 11: Japanese GDP by Expenditure}

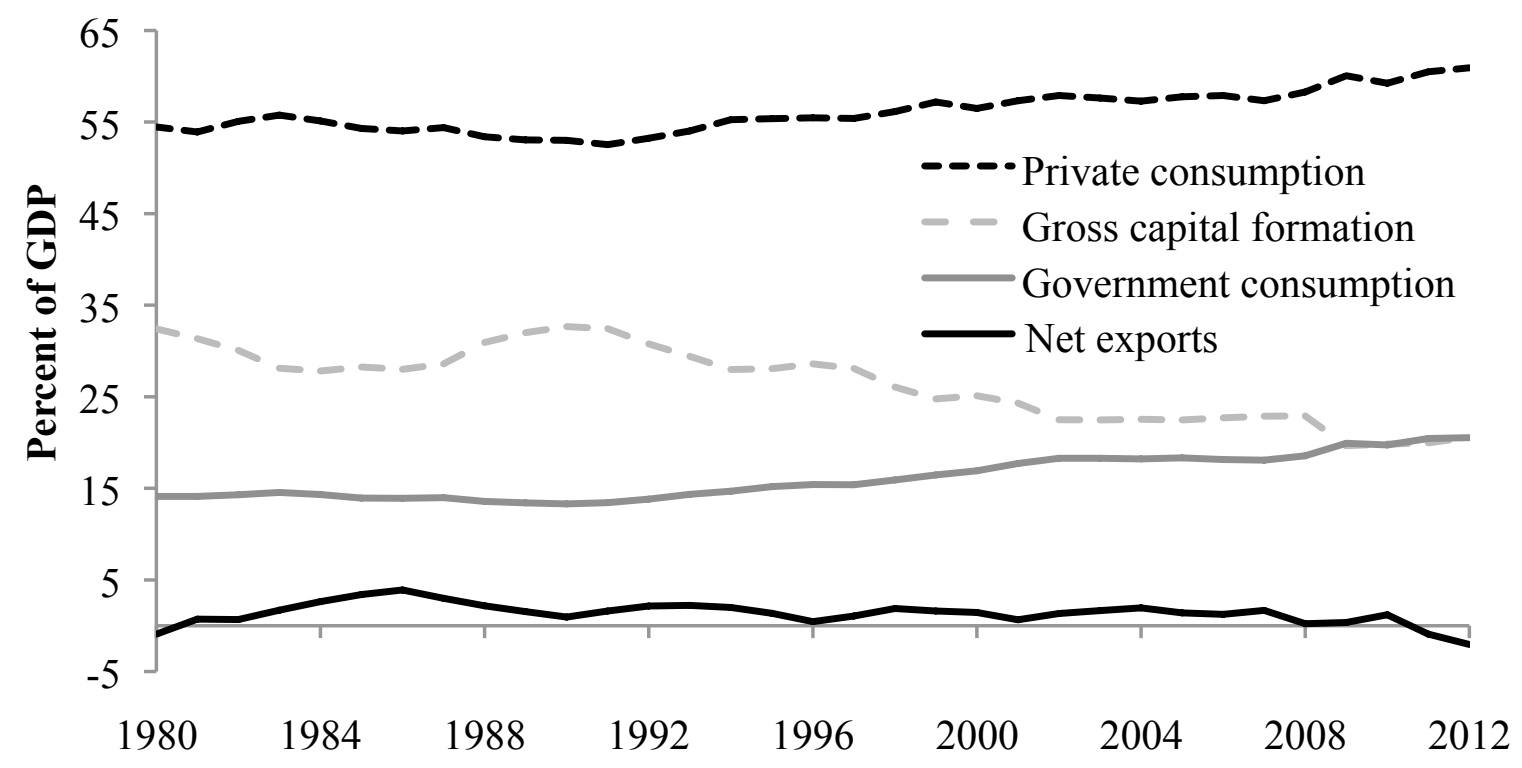

Source: Cabinet Office, Government of Japan.

26 Note that Japanese stock prices have been substantially inflated after the recent announcement of excessive monetary expansion by the Bank of Japan. 


\section{The Wealth Effects of Quasi-Nationalization}

Although the new primeminister Abe has launched a comprehensive program of new fiscal and monetary stimulus in combination with real wage austerity and structural reforms, its long-term success is uncertain. The reason is that in the core of the persistent stagnation the quasi-nationalized finanical sector allocates capital - similarly to former planning economies - based on political criteria rather on the principles of allocation efficiency. Janos Kornai (1993) coined the concept of „soft budget constraints" for enterprises in the Central and Eastern European planning economies. In Japan financial institutions have become reliant on soft buget constraints in form of quasi-unlimited liquidity injections via unconventional monetary policy.

As in the planning economies the borderline between central bank, commercial banks, enterprises and government has become blurred. If the Bank of Japan would lift the interest rate to a level, which would eliminate the structurcal distortions originating in the low interest policies, ${ }^{27}$ the financial sector in Japan would be financially destabilized. The government would have to further increase debt, because substantial parts of the financial sector would have to be recapitalized or nationalized. The already advanced quasi-nationalization of the Japanese financial sector, which extends to the whole economy, would proceed even further.

The price of the creeping quasi-nationalization of the Japanese finanical and enterprise sectors has become obvious not only in form of a stagnating real GDP (Figure 7), but in particular in form of shrinking real personal incomes. Whereas during the bubble economy the incomes from wages and property hiked, the expansionary macroeconomic policies during the postbubble crisis could not prevent the decline of the real incomes of Japanese households (Figure 12). The real wages have been gradually declining since the Japanese financial crisis in 1998 , in average by $1 \%$ per year. The incomes from property (interest, dividends, insurances, rents) have fallen since the bursting of the Japanese bubble even more dramatically, mainly driven by the zero-interest rate policy of the Bank of Japan. They are about $70 \%$ lower than in December 1989 (when the bubble burst) and more than 40\% lower than in 1985 (when the bubble started).

27 Hoffmann and Schnabl (2011) argue that the deviation of the monetary policy rate from Hayek's (1929) natural interest rate - which balances saving and investment - has led to overinvestment cycles, which have cumulated into crisis. 
Figure 12: Real Wage, Interest and Dividend Income in Japan

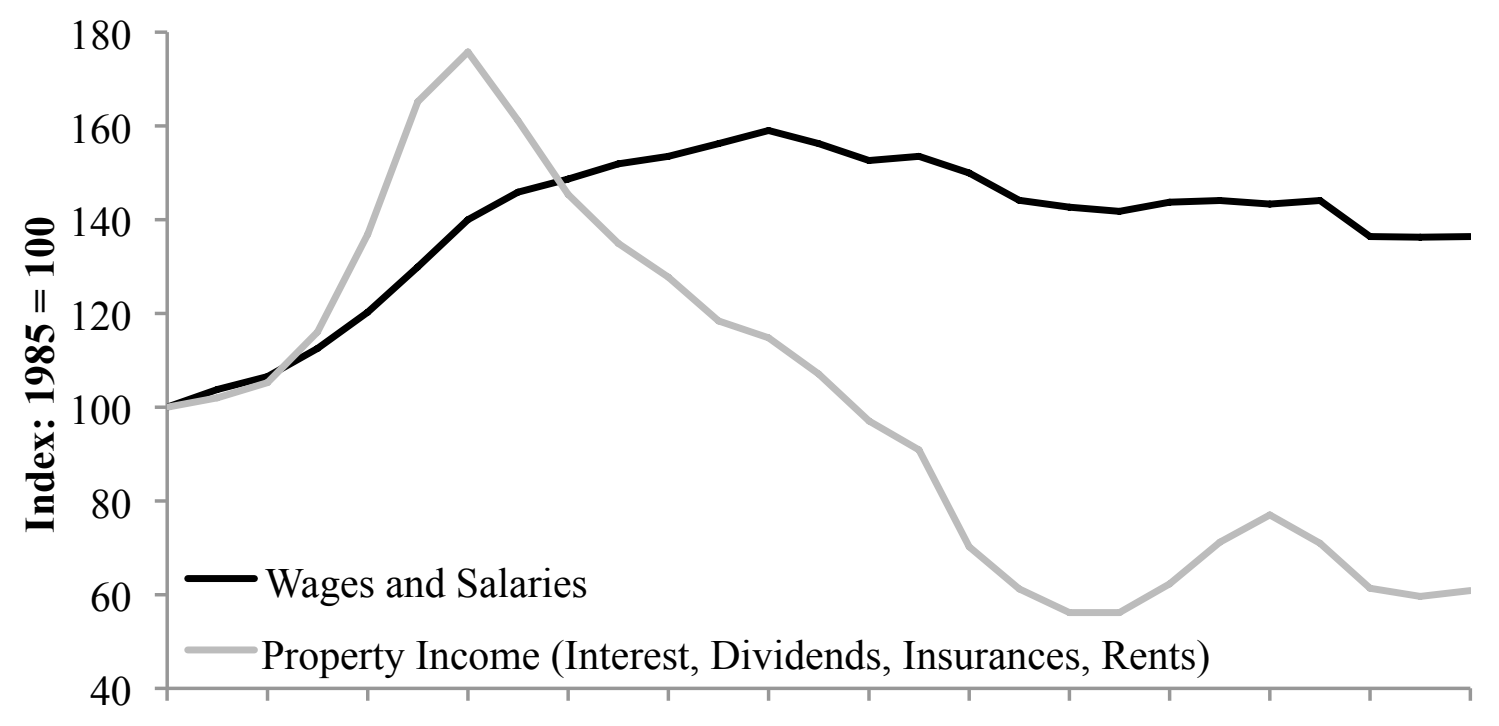

19851987198919911993199519971999200120032005200720092011

Source: Cabinet Office, Government of Japan.

\section{Hayek's Lessons for Japan and Europe}

It seems that Europe has taken a similar path in economic policy patterns in response to the crisis like Japan. Yet, as Hayek (1944: 86) put it: “Any attempt to control prices or quantities of particular commoditites deprives competition of its power of bringing about an effective coordination of individual efforts, because price changes then cease to register all relevant changes in circumstances and no longer provide a reliable guide for the individual's action." Hayek (1944: 103) further stressed: "Although the state controls directly the use of only a large part of the available resources, the effects of its decisions on the remaining part of the economic system become so great that indirectly it controls almost everything." What Hayek fitted back in the 1940s for the means of industrial productions in Germany and the Central and Eastern European planning economies seems to apply today to the Japanese and (increasingly) the European financial sectors. The control of interest rates and credit allocation via unconventional monetary policy has triggered in Japan a quasi-nationalization of the financial and enterprise sectors and therefore the creeping advent of a quasi-planning economy in form of pervasive soft budget constraints. In Europe, in response to the European debt, financial and economic crisis a similar path seems to be taken. 
The longer the crises smolder, the more monetary policy and fiscal policy are used as tools to preserve financial and economic stability. Expansionary monetary policy in the face of crisis has become to be regarded as as indispensable tool to stabilize finanical markets and employment. Yet, this type of economic stimulus can only help to stabilize in the long-term employment if it works symmetrically: Fiscal and monetary expansions during recessions have to be matched by symmetric fiscal and monetary tightening during the recovery after the boom. Otherwise - given the asymmetric realization of macroeconomic policies - the gradual decline of the interest rates and the gradual increase of government debt lead into a quasinationalization of the financial sector, the evergreening of bad loans, a systematic substitution of private investment by public demand, a declining marginal efficiency of investment, the cementation of structural distortions, and the erosion of real income and wealth. The negative impact of this process on political stability will be amplified by rising income inequality, which is a globally visible unintended side effect of excessive monetary expansion.

If Keynesian macroeconomic stimulus was not able to reanimate the Japanese growth during the last two decades, in the spirit of Hayek $(1929,1944)$, the inversed process, i.e. gradual macroeconomic consolidation, should be seen as the appropriate strategy towards a sustained economic recovery. If in the long-term the extensive macroeconomic expansion of the past two decades has led to declining growth, a gradual monetary tightening should lead - despite deflationary effects in the short term - to the revival of Japan's and Europe's economic dynamics. The marginal efficiency of investment would increase and rising shares of economic activity would be reallocated to the private sector and open markets.

As gradual asymmetric interest rate cuts have favored in the past speculation and crisis, a gradual increase of the interest rate level would reduce speculative activities and contribute to a steadier economic devolopment. The marginal efficiency of investment would increase after having declined for two decades. As rising government debt could not sustainably revive economic development, a consolidation of the government debt would free resources for private investment and would allow the return to an independent, stability oriented monetary policy both in Japan and Europe. Economic sentiments and growth perspective would clear up to path the way out of the lingering crises. 


\section{References:}

Abad, José / Löffler, Axel / Schnabl, Gunther / Zemanek, Holger (2012), "Fiscal Divergence, Current Account and TARGET2 Imblances in the EMU", Intereconomics 48, 1, 51-58.

Bayoumi, Tamim / Collyns, Charles (2000), PostBubble Blues. How Japan Responded to Asset Price Collapse, International Monetary Fund, Washington D.C.

Bernanke, Ben (2000), “Japanese Monetary Policy: A Case of Self-Induced Paralysis?”, in: Mikitani, Ryoichi and Posen, Adam (eds.), Japan's Financial Crisis and Its Parallels to U.S. Experience, Institute for International Economics, Washington D.C., 149-166.

Berger, Helge / Nitsch, Volker (2010), “The Euro's Effect on Trade Imbalances.” IMF Working Paper 10/226.

Caballero, Ricardo / Hoshi, Takeo, / Kashyap, Anil (2008), "Zombie Lending and Depressed Restructuring in Japan”, American Economic Review 98, 5, 1943-1977.

Carpenter, Seth / Ihrig, Jane / Klee, Elizabeth / Boote, Alexander / Quinn, Daniel (2012): "The Federal Reserve's Balance Sheet: A Primer and Projections", Federal Reserve Board Finance and Economics Discussion Series 2012/56.

De Grauwe, Paul (2011), "The European Central Bank: Lender of Last Resort in the Government Bond Markets?", CESifo WorkingPaper 3569.

Fischer, Irving (1933), "Debt-Deflation Theory of Great Depression", Econometrica 1, 4, 337-357.

Funabashi, Yoichi (1989), Managing the Dollar: From the Plaza to the Louvre, Institute of International Economics, Washington D.C.

Goyal, Rishi / McKinnon, Ronald (2003), “Japan's Negative Risk Premium in Interest Rates: The Liquidity Trap and the Fall in Bank Lending", The World Economy 26, 339-363.

Hayek, Friedrich August von (1929), Geldtheorie und Konjunkturtheorie, Salzburg, Philosophia Verlag, Reprint 1976.

Hayek, Friedrich August von (1944), The Road to Serfdom, Routledge, London.

Hoffmann, Andreas / Schnabl, Gunther (2011), "A Vicious Cycle of Manias, Bursting Bubbles and Asymmetric Policy Responses - An Overinvestment View." The World Economy 34, 3, 382-403.

Ishikawa, Daisuke / Tsutsui, Yoshiro (2005), "Has a Credit Crunch Occurred in Japan?", RIETI Discussion Paper 06-E-012.

Iwata, Kazumasa / Takenaka, Shinji (2011), "Central Bank Balances Sheet Expansion: Japan's Experience”, BIS Working Paper 66.

Kornai, János (1986), “The Soft Budget Constraint”, Kyklos 39, 1, 3-30. 
Krugman, Paul (2012): "End This Depression Now." New York and London, W. W. Norton \& Company".

McKinnon, Ronald / Ohno, Kenichi (1997), Dollar and Yen: Resolving Economic Conflict between the United States and Japan, MIT Press, Cambridge, Massachusetts.

McKinnon, Ronald (2012), "Zero Interest Rates in the United States Provoke World Monetary Instability and Constrict the U.S. Economy", SIEPR Policy Brief, Stanford, August 2012.

McKinnon, Ronald / Schnabl, Gunther (2004), "The Return to Soft Dollar Pegging in East Asia? Mitigating Conflicted Virtue", International Finance 7, 2, 169-201.

Mikitani, Ryoichi / Posen, Adam (eds.), Japan's Financial Crisis and Its Parallels to U.S. Experience, Institute for International Economics, Washington D.C.

Peek, Joe / Rosengren, Eric (2005), "Unnatural Selection: Perverse Incentives and the Misallocation of Credit in Japan", American Economic Review 95, 4, 1144-1166.

Polleit Thorsten (2011), "Eine Rekapitalisierung der Banken wird die Kreditkrise nicht lösen”, Blog Wirtschaftliche Freiheit, 26.10.2011.

Posen, Adam (2000), "The Political Economy of Deflationary Monetary Policy”, in: Mikitani, Ryoichi and Posen, Adam (eds.), Japan's Financial Crisis and Its Parallels to U.S. Experience, Institute for International Economics, Washington D.C., 194-208.

Schnabl, Gunther (2012), "Monetary Policy Reform in a World of Central Banks", Working Papers on Global Financial Markets 26.

Schnabl, Gunther / Hoffmann, Andreas (2008), "Monetary Policy, Vagabonding Liquidity and Bursting Bubbles in New and Emerging Markets - An Overinvestment View", The World Economy 31, 9, 1226-1252.

Schnabl, Gunther / Zemanek, Holger (2011): Inter-Temporal Savings, Current Account Imbalances and Asymmetric Shocks in a Heterogeneous European Monetary Union. Intereconomics 46, 3, 153-160.

Schnabl, Gunther / Wollmershäuser, Timo (2012), "Fiscal Divergence and Current Account Imbalances in Europe", CESifo Working Paper 4108.

Sekine, Toshitaka / Kobayashi, Keiichiro / Saita, Yumi (2003), "Forbearance Lending: The Case of Japanese Firms", Bank of Japan Institute for Monetary and Economic Studies 21, 2, 69-92.

Shimizu, Yoshinori (2000), "Convoy Regulation, Bank Management and the Financial Crisis in Japan", in: Mikitani, Ryoichi and Posen, Adam (eds.), Japan's Financial Crisis and Its Parallels to U.S. Experience, Institute for International Economics, Washington D.C., $57-$ 99. 
Sinn, Hans-Werner / Wollmershäuser, Timo (2012), "Target Loans, Current Account Balances and Capital Flows: the ECB's Rescue Facility", International Tax and Public Finance 19, 4, 468-508.

Ueda, Kazuo (2012), "Deleveraging and Monetary Policy: Japan since the 1990s and the United States since 2007”, The Journal of Economic Perspectives 26, 3, 177-201.

Yoshino, Naoyuki / Mizoguchi, Tetsuro (2010), "The Role of Public Works in the Political Business Cycle and the Instability of the Budget Deficits in Japan”, Asian Economic Papers9, 1, 94-112.

Yoshino, Naoyuki (2011), "Current State of Japanese Economy and Fiscal Budget Rule to Avoid Budget Explosion",Paper presented at the Shadow G20 Workshop of the International Policy Advisory Group, Paris.

Yoshino, Naoyuki (2013), "The Background of Hometown Investment Trust Funds" in Yoshino, Naoyuki / Kaji, SAhoko (eds.): Hometown Investment Trust Funds: A Stable Way to Supply Risk Capital, Springer, Tokyo, 1-13.

Zemanek, Holger (2010): Competitiveness within the Euro Area: the Problem that Still Needs to be Solved. Economic Affairs 30, 3, 42-47. 